\title{
SEBARAN SPASIAL, KELIMPAHAN DAN STRUKTUR KOMUNITAS ZOOPLANKTON DI ESTUARI SUNGAI SIAK SERTA FAKTOR-FAKTOR YANG MEMPENGARUHINYA
}

\author{
Khairul Amri' ${ }^{1}$, Asep Ma'mun ${ }^{1}$, Asep Priatna ${ }^{1}$, Ali Suman ${ }^{1}$, Eko Prianto ${ }^{2}$ dan Muchlizar ${ }^{3}$ \\ ${ }^{1}$ Balai Riset Perikanan Laut, Cibinong \\ Komplek Raiser, Jl. Raya Bogor KM 47. Nanggewer Mekar, Cibinong, Bogor. 16912 \\ ${ }^{2}$ Jurusan Manajemen Sumberdaya Perairan, Fakultas Perikanan dan Kelautan, Universitas Riau, Pekanbaru \\ ${ }^{3}$ Dinas Perikanan Kabupaten Bengkalis, Riau \\ Email: khairulamriuyu@gmail.com; kh_amri@yahoo.com
}

\begin{abstract}
ABSTRAK
Penelitian ini bertujuan mengetahui pola sebaran, kelimpahan dan struktur komunitas zooplankton di perairan estuari Sungai Siak. Penelitian dilaksanakan selama tujuh bulan (April-Nopember 2015) dengan jumlah stasiun pengambilan sampel sebanyak 16 titik. Hasil penghitungan dianalisis lebih lanjut untuk mengetahui pola sebaran, jumlah jenis, kelimpahan, indeks keanekaragaman, indeks dominasi dan indeks keseragaman. Hasil analisis data, diperoleh jumlah jenis zooplankton yang ditemukan sebanyak 21 jenis terdiri dari kelompok Crustacea sebanyak 8 jenis, Ciliata sebanyak 11 jenis dan Sarcodina sebanyak 2 jenis. Kelimpahan zooplankton di masing-masing stasiun pengamatan berkisar antara $1.570-38.512 \mathrm{ind} / \mathrm{m}^{3}$. Struktur komunitas zooplankton di muara Sungai Siak ditandai dengan indeks keanekaragaman yang tinggi (>3), keseragaman tinggi dan indek dominansi yang rendah. Terdapat dua jenis zooplankton dominan di estuari Sungai Siak yaitu Tintinnopsis radix dan Leprotintinnus nordgvisti masing-masing ditemukan pada November dan Juni. Kelimpahan zooplankton dipengaruhi tingkat kecerahan perairan. Pada saat kecerahan rendah, jumlah jenis zooplankton di perairan ini sangat rendah. Secara umum, kondisi lingkungan perairan estuari Sungai Siak masih mendukung kehidupan zooplankton.
\end{abstract}

Kata Kunci: Indeks Biologi; Plankton; Perairan Selat Bengkalis; Dinamika Estuari.

\section{SPACIAL DISTRIBUTION, ABUNDANCE AND COMMUNITY STRUCTURE OF ZOOPLANKTON IN SIAK RIVER ESTUARY AND RELATED FACTORS THAT INFLUENCE IT}

\begin{abstract}
The aim of study is to determine the distribution pattern, abundance and community structure of zooplankton in the Siak River estuary. The study was conducted for seven months (April-November 2015) with a total of 16 sampling stations. Data were analyzed further to determine the distribution pattern, number of species, abundance, diversity index, dominance index and evenness index of zooplankton. The results showed that there were 21 species of zooplankton consisting of 8 species of Crustaceans, 11 species of Ciliates and 2 types of Sarcodina. Zooplankton abundance in each station ranged from 1,570-38,512 ind $/ \mathrm{m}^{3}$. The zooplankton community structure at the mouth of the Siak River is characterized by a high diversity index (>3), high uniformity and low dominance index. There are two types of zooplankton dominant in the Siak River estuary, namely Tintinnopsis radix and Leprotintinnus nordgvisti, respectively found in November and June. The abundance of zooplankton is influenced by the level of water brightness. When brightness is low, the number of zooplankton in these waters is very low. In general, the environmental conditions of the Siak River estuary waters are still supports zooplankton's life.
\end{abstract}

Key words: Plankton; Biology Index; Bengkalis Strait Waters; Estuary Dynamic.

\section{PENDAHULUAN}

Zooplankton memegang peran penting sebagai sumber makanan bagi biota perairan terutama larva ikan dan udang (Wedderburn et al., 2010). Dalam rantai makanan, zooplankton merupakan konsumer pertama yang memakan fitoplankton dan selanjutnya dimangsa oleh organisme lain yang lebih tinggi tingkatannya (Soedarsono et al., 2002). Sebagai konsumen pertama, keberadaan zooplankton di suatu perairan sangat berpengaruh dalam rantai makanan dan ekosistem perairan (Handayani \& Patria, 2005). Sehingga, dalam kajian ekologi perairan, keberadaan zooplankton tidak dapat diabaikan karena menunjukkan kondisi perairan tersebut (Prianto et al., 2013).
Zooplankton dapat dijumpai mulai dari perairan tawar, payau, estuari sampai ke perairan laut terbuka dan bahkan samudera. Zooplankton yang hidup di perairan estuari, menurut (Nontji, 2008) dimasukkan ke dalam kelompok plankton bahari (haliplankton). Estuari dapat dianggap sebagai zona transisi (ekoton) antara habitat laut dan perairan tawar, yang memiliki karakteristik yang khas (Rositasari \& Rahayu, 1994).

Estuari Sungai Siak yang meliputi perairan muara dan selat, merupakan perairan penting di pesisir Timur Riau. Secara kewilayahan, perairan ini disebut juga sebagai Estuari Bengkalis yang bagian perairannya terdiri dari sub area hilir-muara Sungai Siak; Selat Lalang; Selat Padang; dan Selat Bengkalis (Amri et al., 2018). Perairan ini merupakan habitat dan lokasi spawning ground (pemijahan) sekaligus nursery ground 
(asuhan) beberapa jenis ikan termasuk larva terubuk bengkalis (Tenualosa macrura), ikan endemik yang dikategorikan terancam punah (Merta et al., 1999; Suwarso \& Merta, 2003; Efizon et al., 2012). Oleh karena itu, estuari Sungai Siak telah ditetapkan menjadi kawasan perlindungan terbatas ikan terubuk bengkalis (Efizon \& Alit, 2003).

Sebagai perairan estuaria, ekosistemnya estuari Sungai Siak sangat dinamis, karena dipengaruhi oleh massa air laut bersalinitas lebih tinggi dari Selat Malaka dan massa air tawar dari muara Sungai Siak. Massa air ini kemudian bercampur dengan perluasan massa air bersalinitas rendah dari muara Sungai Kampar yang masuk melalui sub area Selat Lalang, sehingga salinitas perairan ini fluktuatif (Amri et al., 2018-a).

Paterson (1998) menyatakan bahwa komunitas zooplankton sangat sensitif terhadap perubahan lingkungan. Secara umum, plankton estuari miskin dalam jumlah spesies, disebabkan oleh kekeruhan yang tinggi dan cepatnya penggelontoran (Barnes, 1974). Menurut Dianthani (2003) sedikitnya jumlah spesies yang mendiami wilayah estuari dibandingkan habitat air tawar atau air laut di dekatnya, adalah karena ketidakmampuan organisme air tawar mentolerir kenaikan salinitas dan sebaliknya ketidakmampuan organisme air laut mentolerir penurunan salinitas.

Dijelaskan oleh Odum (1998) bahwa keberadaan zooplankton di suatu perairan selain ditentukan oleh faktor-faktor biotik juga faktor abiotik berupa parameter fisika dan kimia perairan. Perubahan fungsi suatu perairan yang meliputi tingkat kemampuan perairan sebagai pendukung kehidupan organisme, bisa dilihat dari perubahan struktur dan kuantitas komunitas plankton di perairan tersebut (Widanyana, 2000). Ini berarti bahwa terjadinya perubahan struktur komunitas plankton, mengindikasikan terjadinya gangguan atau perubahan kondisi pada perairan tersebut.

Kualitas perairan estuaria Sungai Siak dari aspek fisika oseanografi menunjukkan bahwa perairan ini tergolong keruh dengan kecerahan rata-rata $0,42-$ $0,95 \mathrm{~m}$; substrat dasar dominan debu/lumpur 10,64-
89,82\%; rata-rata suhu lapisan permukaan 29,74$30,94{ }^{\circ} \mathrm{C}$ dan di lapisan dasar $29,36-30,63{ }^{\circ} \mathrm{C}$; dan pergerakan arus didominasi oleh arus pasut (arus pasang-surut) dengan kecepatan arus permukaan ratarata berkisar 0,07-1,19 m/detik (Amri et al., 2018-b). Dari aspek kimia oseanografi, nilai sebaran rata-rata bulanan salinitas berkisar antara 6,5-30,7 psu; pH berkisar antara 5,9-8,4; dan DO berkisar antara 2,355,70 ppm dimana nilai $\mathrm{pH}$ dan DO rendah ditemukan di muara Sungai Siak (Amri et al., 2018-c).

Hasil penelitian terdahulu terkait plankton umumnya mengkaji komunitas plankton pada spot-spot tertentu yakni di aliran Sungai Siak (air tawar) seperti dilaporkan (Rahayu et al., 2014) dan (Dwirastina, 2013); di perairan terbatas mulut muara Sungai Siak (Kasry \& El Fajri, 2012); serta di perairan Selat Bengkalis-Selat Rupat (Ariana et al., 2014). Terkait dengan kondisi tersebut, maka penelitian ini bertujuan mengetahui sebaran, kelimpahan dan struktur komunitas zooplankton di estuaria Sungai Siak sebagai daerah asuhan larva terubuk bengkalis, ikan endemik yang kondisinya dinyatakan terancam punah. Sampai saat ini belum ditemukan literatur yang khusus membahas secara konfrehensif zooplankton di estuari Sungai Siak. Diharapkan, informasi yang dihasilkan dari penelitian ini dapat mengisi kekosongan informasi tersebut.

\section{METODE}

\section{Lokasi dan Pengambilan Sampel}

Penelitian ini dilaksanakan di estuaria Sungai Siak, Provinsi Riau, meliputi perairan bagian hilir dan muara Sungai Siak, Selat Lalang, Selat Padang dan Selat Bengkalis dengan jumlah stasiun pengambilan sampel sebanyak 16 titik (Gambar 1). Penelitian dilakukan pada tahun 2015 menggunakan kapal KM. Tenualossa (10 GT) milik Dinas Kelautan dan Perikanan Kabupaten Bengkalis. Pengambilan sampel dilakukan selama 3-4 hari cruise pada setiap bulan (April, Mei, Juni, Agustus, September, Oktober dan Nopember).

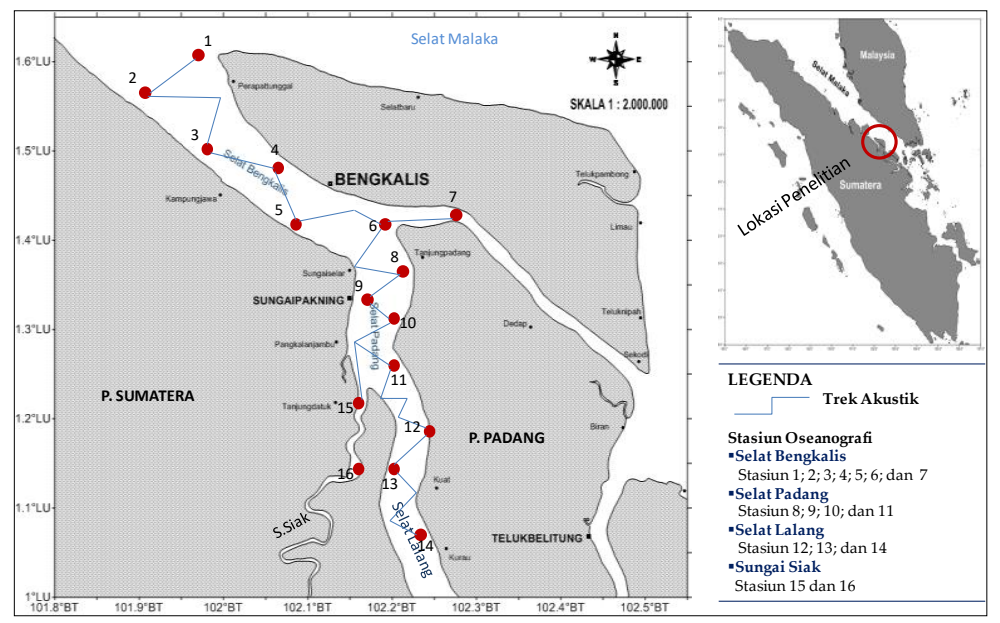

Gambar 1 Peta stasiun pengambilan sampel 
Sampel zooplankton diperoleh dengan cara menyaring air di lokasi penelitian menggunakan plankton net. Spesifikasi zooplankton net adalah diameter mulut jaring $45 \mathrm{~cm}$, panjang jaring $180 \mathrm{~cm}$ dan ukuran mata jaring 0,3 mm. Pengoperasian zooplankto net dengan menarik secara vertikal sampai kedalaman 10-20 m (tergantung kedalaman perairan di lokasi sampling) dengan rata-rata volume air tersaring $0,48 \mathrm{~m}^{3}$. Sampel zooplankton dari 16 stasiun pengukuran, masing-masing diawetkan dengan formalin $4 \%$ pada masing-masing botol bervolume $250 \mathrm{ml}$.

\section{Pengolahan dan Analisis Data}

Pengamatan meliputi identifikasi jenis dan pencacahan jumlah individu untuk setiap jenis zooplankton. Pencacahan dan penghitungan dilakukan menggunakan mikroskop binokuler dengan mengikuti metode sapuan, yaitu mencacah semua jenis plankton yang ada dalam volume air contoh. Identifikasi zooplankton mengacu Yamaji (1979) dan Tomas (1997). Hasil penghitungan kemudian dianalisis lebih lanjut untuk memperoleh nilai komposisi, kelimpahan dan indeks komunitas (indeks keanekaragaman, indeks dominasi dan indeks keseragaman jenis) yang mengacu pada referensi (Ludwig \& Reynolds 1988).

Pengamatan kelimpahan plankton dilakukan menurut American Public Health Association (APHA) (1980) dengan rumus sebagai berikut :

$$
\mathrm{N}=\frac{\mathrm{Ns} \times \mathrm{Va}}{\mathrm{Vs} \times \mathrm{Vc}}
$$

Keterangan :

$\mathrm{N}=$ Kelimpahan plankton (cell/l) atau (ind/l)

Ns = Jumlah plankton pada sedgwick-rafter

$\mathrm{Va}=$ volume air yang terkonsentrasi dalam contoh (ml)

$\mathrm{V}_{\mathrm{s}}=$ Volume air dalam preparat sedgwick-rafter $(\mathrm{ml})$

$\mathrm{Vc}=$ Volume air contoh yang disaring $(\mathrm{ml})$

Indeks keanekaragaman $(\mathrm{H})$ dihitung dengan menggunakan persamaan "Shannon-Wiener" dengan rumus :

$$
H^{\prime}=-\sum\left[\left(n_{i} / N\right) / \operatorname{Ln}\left(n_{i} / N\right)\right]
$$

dimana :

$\mathrm{N}=$ total plankton (individu atau sel) untuk semua spesies,

$\mathrm{n}_{\mathrm{i}}=$ jumlah plankton (individu atau sel) untuk spesies ke $i$.

Indeks keseragaman (E) dihitung dengan menggunakan persamaan dari Pielou (1975) dengan rumus :

$$
\mathrm{E}=\mathrm{H}^{\prime} / \operatorname{Ln}(\mathrm{s})
$$

dimana :

$\mathrm{S}$ = banyaknya spesies

$\mathrm{H}^{\prime}=$ indeks Shannon-Wiener
Indeks dominansi jenis (D) dihitung berdasarkan indeks Simpson, dengan rumus:

$$
D=\sum\left[\frac{n_{i}}{N}\right]^{2}
$$

Dimana:

$\mathrm{n}_{\mathrm{i}}=$ jumlah plankton (individu atau sel) untuk spesies ke $i$

$\mathrm{N}=$ jumlah total plankton (individu atau sel) semua spesies

Nilai indek keseragaman (E) dan indeks dominasi (D) umumnya berkisar antara 0-1. Dengan kriteria Odum (1993), semakin kecil nilai E menunjukkan bahwa penyebaran jumlah individu tiap jenis tidak sama dan tidak ada spesies yang mendominasi. Sebaliknya, semakin besar indeks E dan D maka kesamaan dalam penyebaran jumlah individu tiap jenis semakin tinggi serta ada spesies tertentu yang mendominasi.

Tampilan indeks dalam bentuk grafik dilakukan dengan menggunakan apliksi Excel 2010 dan ploting data dalam bentuk pola sebaran zooplankton dilakukan menggunakan software Surfer Ver.12. Analisis keterkaitan kelimpahan dan sebaran zooplankton dengan faktor-faktor yang diduga mempengaruhinya dilakukan secara deskriptif.

\section{HASIL DAN PEMBAHASAN}

\section{Jenis-jenis Zooplankton}

Jenis-jenis zooplankton yang ditemukan sebanyak 21 jenis terdiri dari kelas Crustacea ( 8 jenis); kelas Ciliata (11 jenis) dan kelas Sarcodina ( 2 jenis) (Tabel 1). Jika dilihat dari jumlah jenisnya, menunjukkan bahwa perairan estuari Sungai Siak lebih banyak dihuni oleh zooplankton dari Filum Prozoa yaitu dari Kelas Ciliata dan Sarcodina (13 jenis) dibanding Filum Athrophoda yaitu dari kelas Crustacea (8 jenis). Kelas Ciliata terdiri dari Sub Kelas Spirotricha (Famili Codonelpsidae; Cyttarocyclidae; dan Tintinnidae) dan Sub Kelas Holotricha (Famili Holophryidae); serta Kelas Sarcodina dari Sub Kelas Rizophoda (Famili Globigerinidae). Disusul kemudian zooplankton dari Kelas Crustasea yakni sub kelas Copepoda (famili Acartiidae; Macrosetellidae; dan Oithonidae).

\section{Jumlah Taxa dan Kelimpahan}

Jumlah jenis (taxa) dan kelimpahan zooplankton yang ditemukan pada masing-masing stasiun pengamatan berbeda dan berfluktuasi setiap bulan pengamatan (Tabel 2). 
Khairul Amri: Sebaran Spasial, Kelimpahan dan Struktur Komunitas Zooplankton di Estuari Sungai Siak Serta Faktor-Faktor yang Mempengarui

Tabel 1 Jenis-jenis zooplankton yang ditemukan di estuari Sungai Siak.

\begin{tabular}{|c|c|c|c|c|c|}
\hline Filum & Kelas & Sub Kelas & Famili & & Jenis \\
\hline \multirow{8}{*}{ Athrophoda } & Crustasea & Copepoda & Acartiidae & 1 & Acartea sp. \\
\hline & & & & 2 & Acartea sp. (nauplius) \\
\hline & & & Macrosetellidae & 3 & Macrostella sp.1 \\
\hline & & & & 4 & Macrostella sp.2 \\
\hline & & & Oithonidae & 5 & Oithona sp. \\
\hline & & & & 6 & Oithona sp. (nauplius) \\
\hline & & & & 7 & Copepoda sp.1 \\
\hline & & & & 8 & Copepoda sp.2 \\
\hline \multirow[t]{13}{*}{ Protozoa } & Ciliata & Spirotricha & Codonelopsidae & 9 & Codonellopsis sp. \\
\hline & & & Cyttarocylidae & 10 & Favella campanula \\
\hline & & & & 11 & Favella sp. \\
\hline & & & Tintinnidae & 12 & Leprotintinnus boltnicus \\
\hline & & & & 13 & Leprotintinnus nardgvisti \\
\hline & & & & 14 & Tintinnopsis gracilis \\
\hline & & & & 15 & Tintinnopsis radix \\
\hline & & & & 16 & Tintinnopsis sp.1 \\
\hline & & & & 17 & Tintinnopsis sp.2 \\
\hline & & & & 18 & Tintinnus lasus - undae \\
\hline & & Holotricha & Holophryidae & 19 & Prorodon sp. \\
\hline & Sarcodina & Rizophoda & Globigerinidae & 20 & Globigerina sp.1 \\
\hline & & & & 21 & Globigerina sp.2 \\
\hline
\end{tabular}

Tabel 2 Nilai kelimpahan dan jumlah jenis zooplankton di estuari Sungai Siak.

\begin{tabular}{lcccc}
\hline \multirow{2}{*}{ Bulan } & \multicolumn{2}{c}{ Kelimpahan $\left(\mathrm{ind} / \mathrm{m}^{3}\right)$} & \multicolumn{2}{c}{ Jumlah jenis } \\
\cline { 2 - 5 } & Kisaran & Rerata & Kisaran & Rerata \\
\hline April & $1.570-3.140$ & 2.610 & $12-16$ & 14 \\
Mei & $5.024-7.693$ & 6.231 & $11-15$ & 13 \\
Juni & $6.280-10.833$ & 8.609 & $11-16$ & 14 \\
Agustus & $5.652-7.222$ & 6.437 & $12-17$ & 14 \\
September & $13.944-21.248$ & 18.073 & $6-12$ & 9 \\
Oktober & $17.264-31.208$ & 21.871 & $14-17$ & 15 \\
November & $11.620-18.924$ & 15.993 & $11^{\prime}-15$ & 13 \\
\hline
\end{tabular}

Jumlah jenis zooplankton berkisar antara 6-17 taxa (kisaran rata-rata 9-15 taxa setiap bulan pengamatan) dengan jumlah jenis terendah (6 jenis) pada bulan September (Stasiun 16: Sungai Apit) dan tertinggi (17 jenis) pada bulan Agustus (Stasiun 14: Selat Lalang) dan Oktober (Stasiun 1 dan 7: Selat Bengkalis). Kelimpahan zooplankton berkisar antara 1.570 individu/ $\mathrm{m}^{3}-31.208$ $\mathrm{ind} / \mathrm{m}^{3}$ (kisaran rata-rata $2.610-21.871 \mathrm{ind} / \mathrm{m}^{3}$ per bulan pengamatan). Kelimpahan zooplankton terendah ditemukan pada bulan April (stasiun 16 di Sungai Apit di bagian hilir Sungai Siak: $1.570 \mathrm{ind} / \mathrm{m}^{3}$ ) dan kelimpahan tertinggi pada bulan Oktober (stasiun 1 di Selat Bengkalis ke arah laut terbuka di Selat Malaka: $31.208 \mathrm{ind} / \mathrm{m}^{3}$ ). Dinamika fluktuasi perubahan kelimpahan dan jumlah taxa zooplankton per stasiun pengamatan menunjukkan pola yang berbeda setiap bulan pengamatan (Gambar 2).

\section{Sebaran Spasial}

Pada pola sebaran secara spasial (Gambar 3), dapat dilihat bahwa sub area perairan sekitar muara Sungai Siak merupakan wilayah perairan dengan konsentrasi zooplankton paling rendah, yang dalam penelitian ini digambarkan sebagai perairan yang dominansi warna biru-hijau di lokasi ini. Adapun perairan Selat Bengkalis ke arah laut terbuka di Selat Malaka merupakan perairan dengan konsentrasi zooplankton paling tinggi (digambarkan sebagai massa air berwarna kuning-merah) dan perairan Selat Lalang berwarna hijau-kuning merupakan perairan dengan konsentrasi zooplankton sedang, digambarkan sebagai massa air berwarna hijau-kuning. 


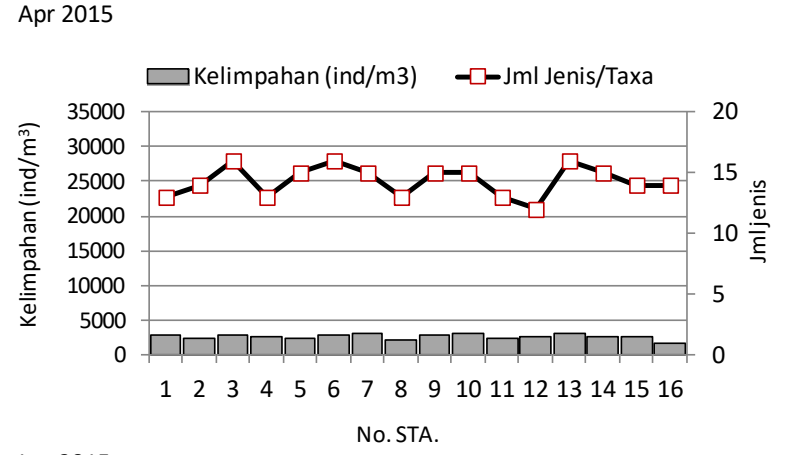

Jun 2015

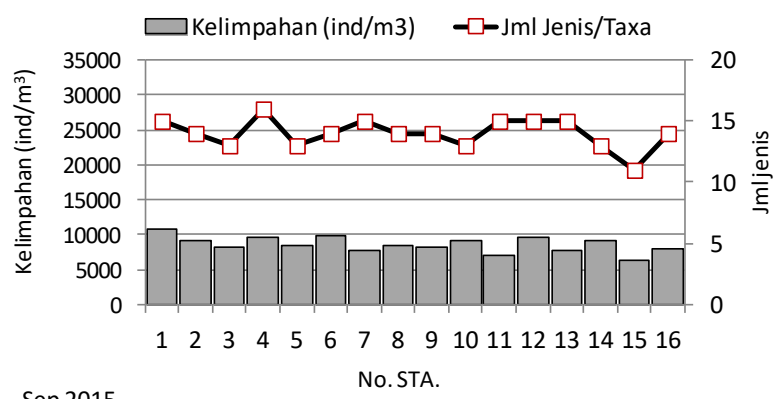

Sep 2015

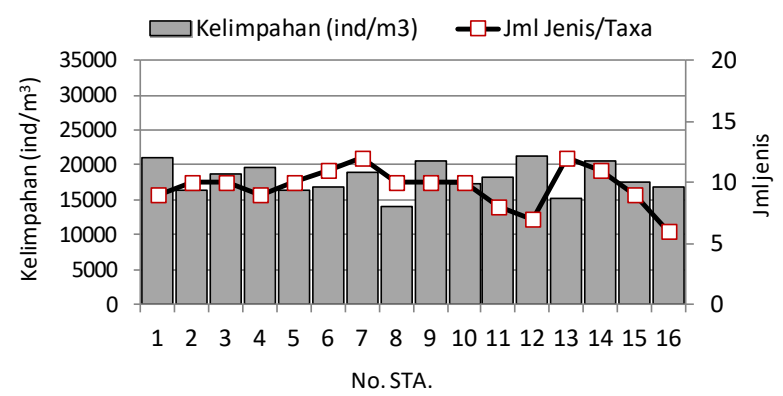

Mei 2015

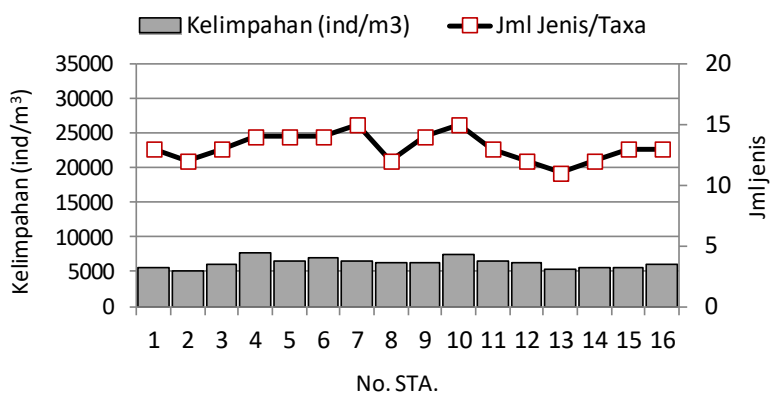

Ags 2015

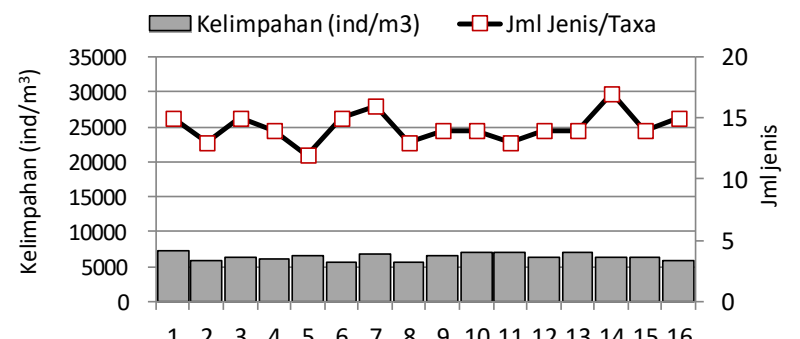

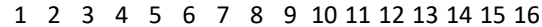

Okt 2015

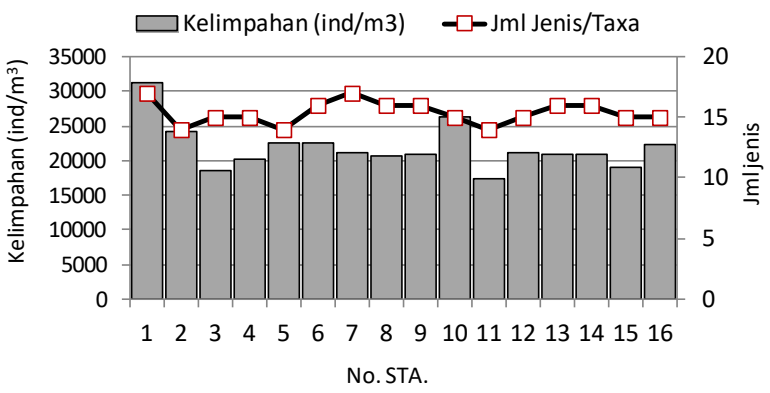

Nov 2015

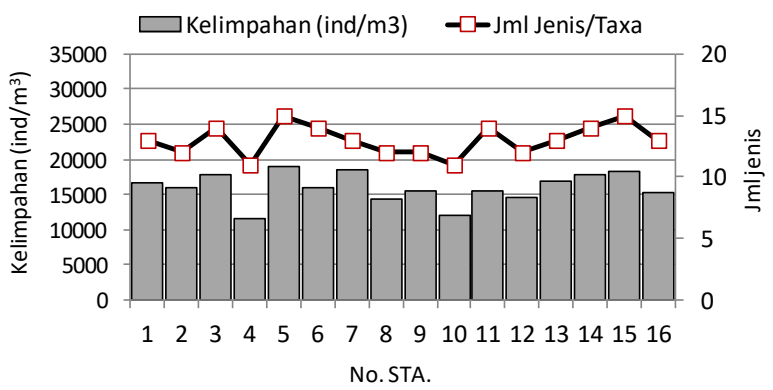

Gambar 2 Fluktuasi kelimpahan dan jumlah jenis zooplankton di estuari Sungai Siak 

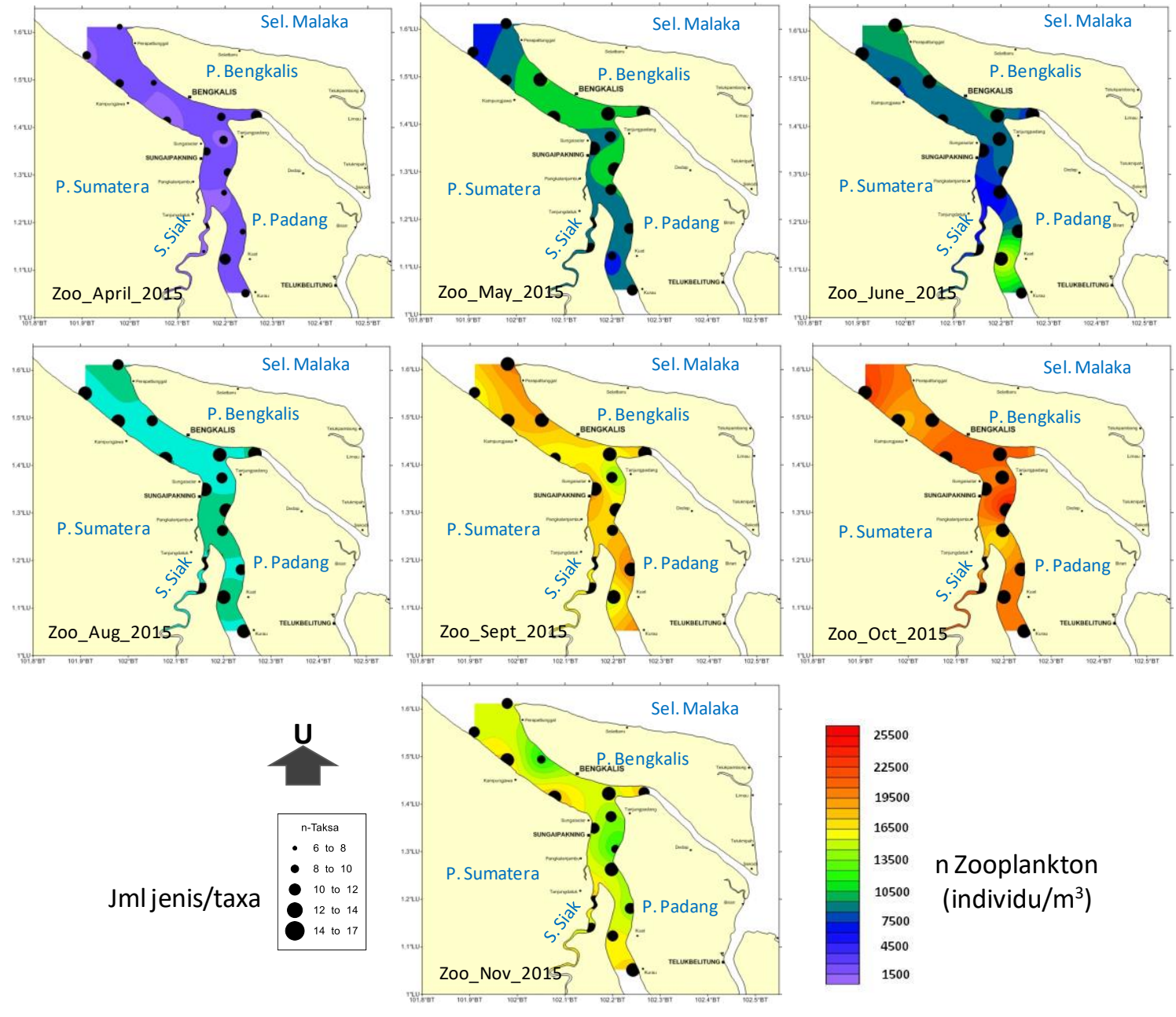

\section{nZooplankton \\ (individu $/ \mathrm{m}^{3}$ )}

Gambar 3 Sebaran spasial dan temporal jumlah jenis dan kelimpahan zooplankton (overlay) di estuari Sungai Siak

Pada bulan April 2015, kelimpahan dan jumlah taxa yang ditemukan di semua stasiun pengamatan umumnya sangat rendah (ditandai perairan berwarna biru dan dominansi bulatan hitam berukuran kecil). Secara gradual terlihat peningkatan kelimpahan per bulannya dengan perubahan warna menjadi hijau kemudian kuning (September) dan selanjutnya merah menandahkan kelimpahan tinggi (Oktober 2015). Kelimpahan zooplankton mengalami penurunan pada bulan November (warna kuning).

Dari pola warnanya, terlihat bahwa pengkayaan zooplankton di estuari Sungai Siak berasal dari aliran massa air yang berasal dari laut terbuka ke arah Selat Malaka, yang masuk ke estuari Sungai Siak melalui sub area Selat Bengkalis (massa air berwarna kuningmerah). Selain itu, juga terlihat spot-spot pengkayaan zooplankton dari massa air yang berasal dari Selat Lalang (massa air berwarna hijau-kuning). Dari penggambaran secara spasial ini juga terlihat bahwa peningkatan jumlah taxa zooplankton sejalan dengan peningkatan kelimpahannya. Pada bulan April, saat kelimpahan rendah (dominansi massa air warna biru muda-biru) jumlah taxa nya pun rendah (bulatan hitam berukuran kecil). Sebaliknya, pada saat kelimpahan tinggi pada bulan September-Oktober (dominansi massa air berwarna kuning-merah), jumlah jenis atau taxa zooplankton pun lebih banyak (bulatan hitam berukuran lebih besar).

\section{Indeks Komunitas}

Nilai indeks keanekaragaman $\left(\mathrm{H}^{\prime}\right)$; indeks keseragaman jenis (E); dan indeks dominansi (D) per stasiun pengukuran per bulan pengamatan dapat dilihat (Tabel 4: Lampiran 1) dan kisaran nilai serta nilai ratarata masing-masing indeks tersebut per bulan pengamatan seperti tertera pada Tabel 3 .

Secara umum, indeks keanekaragaman $\left(\mathrm{H}^{\prime}\right)$ dan indek keseragaman (E) jenis zooplankton di estuari Sungai Siak tergolong tinggi dan berbeda nilainya antar bulan pengamatan dan stasiun sampling (Gambar 4). Nilai indeks keanekaragaman jenis $\left(\mathrm{H}^{\prime}\right)$ pada masing-masing lokasi tergolong tinggi yakni rata-rata $>3$, kecuali pada bulan September dan November ditemukan indeks keanekaragaman jenis dengan kategori sedang (1-3) yakni di Stasiun 1, 11 dan 12 (September) dan Stasiun 7 (November) dengan nilai 
indek <3. Tinggi rendahnya nilai indeks keanekaragaman jenis zooplankton di suatu perairan dipengaruhi oleh beberapa faktor, di antaranya salinitas dan arus air sungai. Nilai indeks keseragaman (E) zooplankton yang dalam penelitian ini berkisar antara 0,833-0,976, juga tergolong tinggi, karena nilainya mendekati 1. Hal ini menunjukkan penyebaran individu jenis atau genera zooplankton di estuari Sungai Siak tersebar merata.

Tabel 3 Nilai kisaran dan rata-rata indeks biologi zooplankton di estuari Sungai Siak.

\begin{tabular}{|c|c|c|c|c|c|c|}
\hline \multirow{3}{*}{ Bulan } & \multicolumn{6}{|c|}{ Indeks } \\
\hline & \multicolumn{2}{|c|}{ Keanekaragaman $\left(\mathrm{H}^{\prime}\right)$} & \multicolumn{2}{|c|}{ Keseragaman (E) } & \multicolumn{2}{|c|}{ Dominansi (D) } \\
\hline & Kisaran & Rata-rata & Kisaran & Rata-rata & Kisaran & Rata-rata \\
\hline April & $3,439-3,907$ & 3,66 & $0,917-0,976$ & 0,947 & $0,08-0,18$ & 0,18 \\
\hline Mei & $3,266-3,682$ & 3,47 & $0,905-0,958$ & 0,936 & $0,09-0,12$ & 0,12 \\
\hline Juni & $3,156-3,698$ & 3,52 & $0,934-0,941$ & 0,930 & $0,08-0,34$ & 0,34 \\
\hline Agustus & $4,852-5,164$ & 5,04 & $0,843-0,916$ & 0,895 & $0,08-0,12$ & 0,12 \\
\hline September & $2,446-3,422$ & 3,08 & $0,917-0,976$ & 0,947 & $0,10-0,20$ & 0,20 \\
\hline Oktober & $3,192-3,743$ & 3,51 & $0,838-0,943$ & 0,893 & $0,08-0,12$ & 0,12 \\
\hline November & $2,566-3,601$ & 3,40 & $0,895-0,958$ & 0,937 & $0,09-0,42$ & 0,42 \\
\hline
\end{tabular}
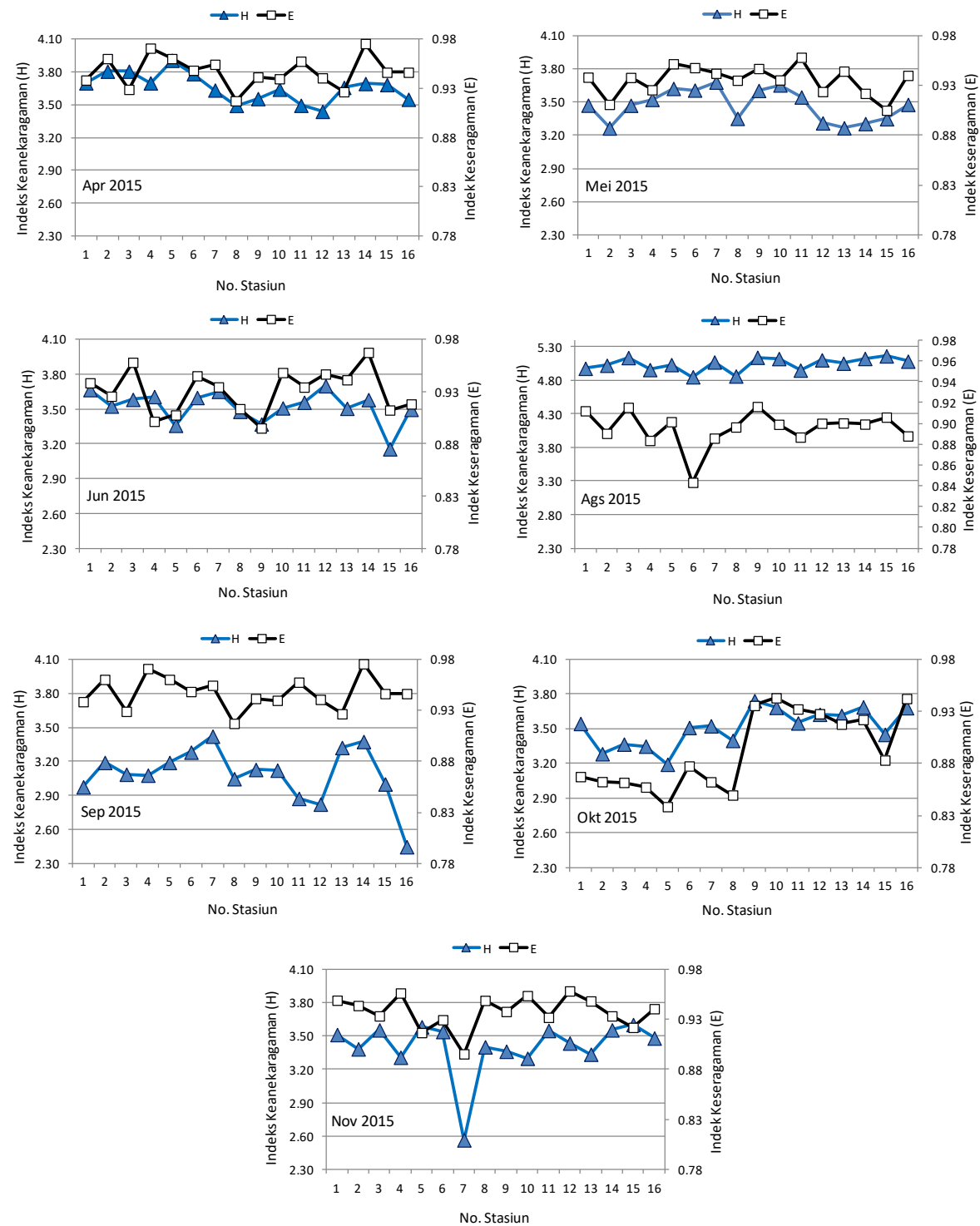

Gambar 4 Indeks keanekaragaman jenis dan keseragaman zooplankton di muara Sungai Siak. 
Adapun nilai indeks dominansi (D) berkisar antara 0,08-0,42 tergolong kategori rendah (Gambar 5). Nilai indeks dominansi tertinggi $(0,42)$ ditemukan di stasiun 7 pada bulan November. Nilai indeks dominansi yang umumnya rendah mengindikasikan bahwa di estuari Sungai Siak tidak ada spesies zooplankton yang mendominasi. Dari nilai indeks dominansi per stasiun
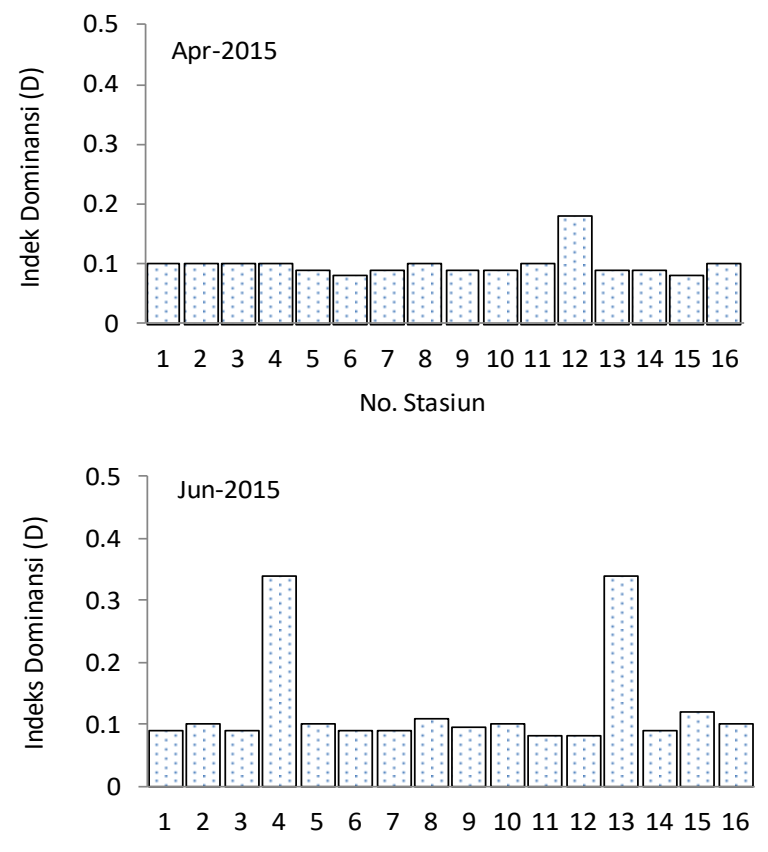

No. Stasiun

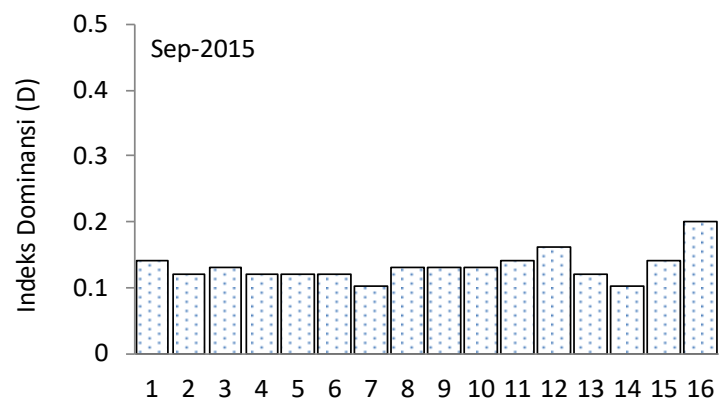

No. Stasiun per bulan pengamatan ini diketahui beberapa lokasi memiliki nilai indeks dominansi >0,3, yaitu bulan November (stasiun 7) dan Juni (stasiun 4 dan 13). Jenis zooplankton yang banyak ditemukan pada lokasi tersebut adalah Tintinnopsis radix (November) dan Leprotintinnus nardgvisti (Juni).
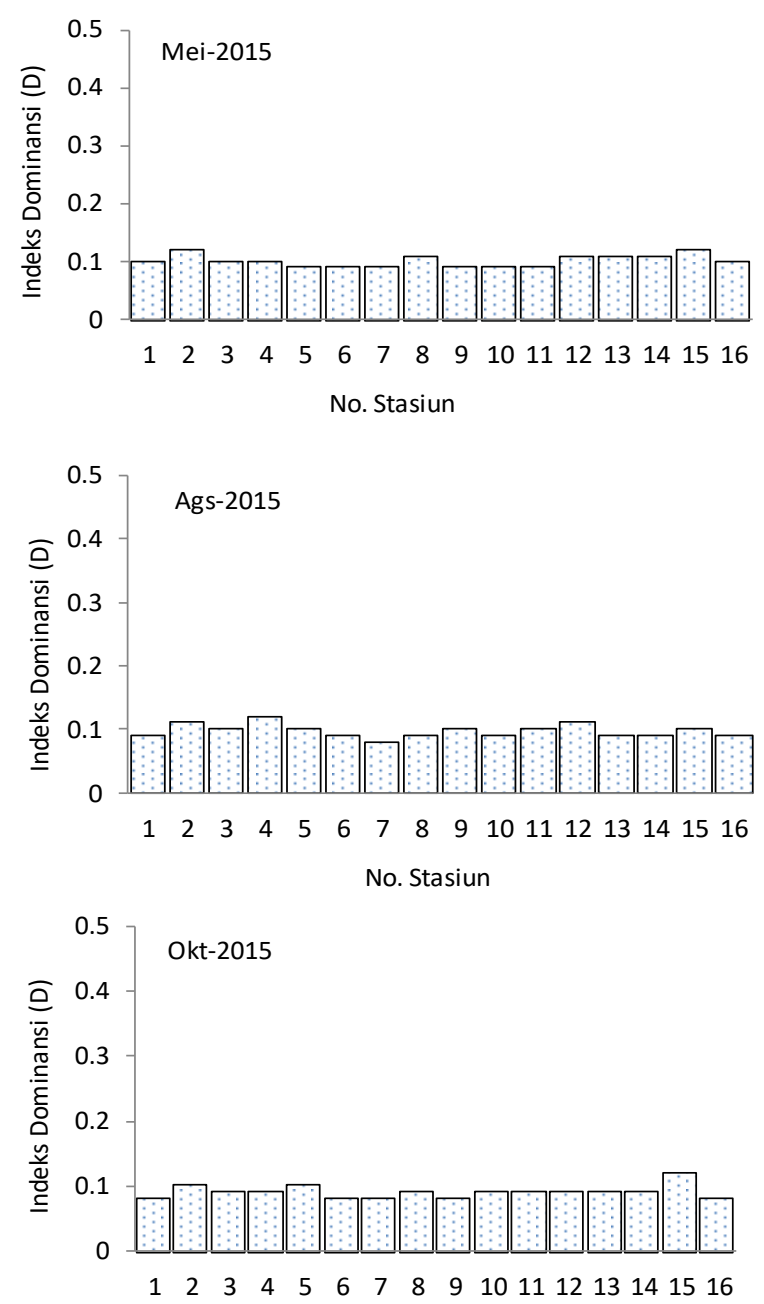

No. Stasiun

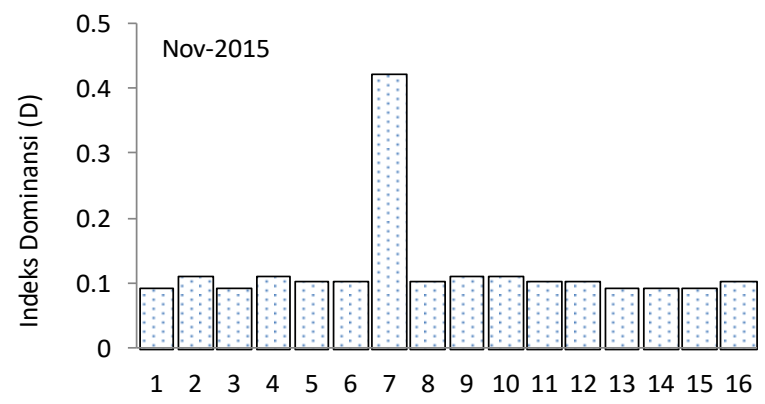

No. Stasiun

Gambar 5 Indeks dominansi zooplankton di muara Sungai Siak. 


\section{PEMBAHASAN}

Kelimpahan zooplankton di estuari Sungai Siak yang berfluktuasi dan umumnya rendah pada awal tahun (April) diduga terkait dengan masih tingginya penggelontoran massa air tawar di Sungai Siak pada penghujung musim hujan. Pada saat itu, massa air di estuari Sungai Siak selain bersalinitas rendah juga didominasi massa air gambut (Amri et al., 2018-a). Itu sebabnya, dari pola sebaran spasial terlihat massa air dengan kelimpahan dan juga jumlah taxa/jenis zooplankton yang rendah ditemukan hampir merata di seluruh area estuari Sungai Siak.

Sebaliknya, ketika aliran massa air tawar berkurang, kelimpahan dan jumlah jenis zooplankton mulai meningkat pada bulan-bulan berikutnya seiring masuknya musim kemarau. Pada saat kemarau, dorongan massa air bersalinitas lebih tinggi dari Selat Malaka yang masuk ke estuari Sungai Siak melalui Selat Bengkalis, terlihat semakin dominan (Amri et al., 2018a) dan ini meningkatkan kelimpahan dan jumlah jenis zooplankton di perairan ini. Puncaknya adalah pada bulan Oktober, merupakan periode ditemukan kelimpahan dan jumlah jenis zooplankton tertinggi selama penelitian ini. Selanjutnya, pada bulan November, ketika mulai memasuki musim hujan, kelimpahan zooplankton mulai mengalami penurunan bersamaan dengan meningkatknya aliran massa air tawar dari Sungai Siak maupun dari muara Sungai Kampar melalui perluasan massa air di Selat Lalang.

Kelimpahan zooplankton terendah (1.570 ind $/ \mathrm{m}^{3}$ ) yang ditemukan pada bulan April (Stasiun $16 \mathrm{di}$ Sungai Apit) berada pada bagian hilir Sungai Siak yang bersalinitas rendah. Sementara kelimpahan tertinggi (31.208 ind $/ \mathrm{m}^{3}$ ) yang ditemukan pada bulan Oktober (Stasiun 1), merupakan sisi terluar Selat Bengkalis yang berhadapan langsung ke arah laut terbuka di Selat Malaka memiliki massa air bersalinitas tinggi. Hal ini mengindikasikan bahwa secara signifikan salinitas perairan berpengaruh besar terhadap kelimpahan zooplankton di estuari Sungai Siak.

Jumlah taxa/jenis zooplankton yang ditemukan di muara Sungai Siak yang berkisar antara 6-17 jenis per bulan (rata-rata 13 jenis per bulan pengamatan) dan terdiri atas 3 kelas (Crustasea, Ciliata, dan Sarcodina) lebih rendah dibandingkan dengan Sungai Musi dan Sungai Banyuasin. Hasil penelitian (Prianto et al., 2008) di Sungai Musi bagian hilir ditemukan setidaknya 35 jenis zooplankton sedangkan hasil penelitian (Prianto $e t$ al., 2013) di Sungai Banyuasin ditemukan sebanyak 18 jenis dan terdiri dari 6 kelas (Ciliata, Rotatoria, Mastigophora, Crustacea, Monogonota dan Protozoa) yang berarti dua kali lebih banyak dari jumlah kelas yang ditemukan di estuari Sungai Siak. Dibandingkan dengan di perairan teluk, jumlah kelas zooplankton di estuari Sungai Siak yang terdiri dari 3 kelas tergolong sedikit. Menurut Rahman et al. (2017), di perairan Teluk
Tomini ditemukan 9 kelas zooplankton dengan kelas Crustaceae dan Sarcodina dengan kelimpahan tertinggi. Rendahnya jumlah jenis zooplankton dan kelimpahan zooplankton yang ditemukan di perairan estuari Sungai Siak khususnya di sub area hilir- muara Sungai Siak (Stasiun 11, 12, 15 dan 16), diduga terkait dengan kualitas air Sungai Siak di lokasi ini yang kondisinya tidak sesuai dengan baku mutu perairan yakni pH dan DO (Dissolved Oxygen / Oksigen terlarut) rendah (Fajri \& Kasry, 2013) dan (Amri et al., 2018). Selain itu, umumnya rendahnya jumlah jenis zooplankton di wilayah estuari juga dapat disebabkan adanya fluktuasi salinitas yang tinggi (Souza Júnior $e t$ al., 2013), sehingga hanya jenis tertentu yang mampu hidup pada kondisi perairan tersebut. Amri et al. (2018a) menyebutkan massa air estuari Sungai Siak memiliki rentang nilai kisaran sebaran salinitas dari 8,5-31,5 psu dengan fluktuasi bulanan mencapai $\pm 3,5$ psu di perairan selat (sub area Selat Bengkalis, Selat Padang dan Selat Lalang) dan $\pm 8,5$ psu di sub area hilir-muara Sungai Siak. Kondisi ini sejalan dengan yang disebutkan da Costa et al. ( 2008) dan Pranoto et al. (2005) bahwa muara merupakan perairan yang sangat dinamis dicirikan dengan perubahan salinitas yang tinggi. Bahkan di estuari Taperacu-Brazil perubahan salinitas cukup besar berkisar 9,1-40 baik di musim hujan maupun musim kemarau (da Costa et al., 2008).

Nybakken (1992) menyatakan perairan muara memiliki ciri berfluktuasinya salinitas, yang akan tampak pada saat tertentu, bervariasi bergantung pada musim, topografi muara, pasang surut dan jumlah air tawar. Ciri lain, substrat berlumpur berasal dari sedimen yang dibawa ke dalam muara oleh air laut maupun air tawar. Suhu di muara sungai lebih bervariasi daripada di perairan di dekatnya karena volume air lebih kecil sedangkan luas permukaan lebih besar, dengan demikian pada kondisi atmosfer yang ada, air wilayah hilir ini lebih cepat dingin atau lebih cepat panas.

Kekeruhan juga menjadi ciri perairan ini, dimana kekeruhan tertinggi terjadi saat aliran sungai maksimum yakni pada musim penghujan. Kondisi perairan muara mempengaruhi jumlah spesies zooplankton yang mendiami sistem muara. Sehingga, pada penelitian ini, jumlah jenis zooplankton pada bagian hilir (Stasiun 16) dan muara Sungai Siak (Stasiun 11, 12 dan 15) pada bulan April (penghujung musim hujan) lebih rendah dibandingkan di lokasi lainnya (Selat Lalang dan Selat Bengkalis). Adapun jumlah taxa/jenis zooplankton terendah (rata-rata 9 taxa) yang ditemukan pada bulan September 2015, diduga bukan karena faktor salinitas tetapi terkait dengan puncak bencana asap kebakaran lahan di Riau. Pada saat itu, meskipun salinitas tinggi, namun kabut asap membatasi jarak pandang dan menghalangi penetrasi sinar matahari sehingga tingkat kecerahan perairan pada saat itu umumnya sangat rendah (Amri et al., 2018-a). Kondisi ini ternyata mempengaruhi jumlah jenis zooplankton di estuari Sungai Siak. 
Secara umum, kisaran kelimpahan zooplankton di muara Sungai Siak relatif hampir sama dengan ditemukan di Sungai Musi dan Sungai Banyuasin. Hasil penelitian Prianto et al. (2013) kelimpahan zooplankton di Sungai Banyuasin berkisar antara 2-19 ind/l atau 2.000-19.000 ind $/ \mathrm{m}^{3}$ sedangkan Prianto et al. (2008) menyatakan kelimpahan zooplankton di Sungai Musi Bagian Hilir berkisar 0,8-21 ind/l atau 800-21.000 $\mathrm{ind} / \mathrm{m}^{3}$. Selanjutnya hasil penelitian da Costa et al. (2008) di estuaria Taperacu Brazil diperoleh kelimpahan zooplankton yang lebih tinggi berkisar 16.491-397.476 ind $/ \mathrm{m}^{3}$.

Pratiwi et al. (2016) menyatakan kelimpahan zooplankton, distribusi dan struktur komunitasnya sangat dipengaruhi oleh parameter fisika-kimia perairan (seperti arus, angin, gelombang), musim dan aktifitas antropogenik diperairan tersebut. Selama musim kemarau parameter fisika-kimia perairan yang mempengaruhi kelimpahan dan sebaran zooplankton di muara adalah $\mathrm{pH}$, suhu, $\mathrm{NO}_{2}$ dan klorofil (Silva et al., 2009; Mishra \& Panigrahy, 1999) sedangkan musim penghujan adalah total fosfat, kecerahan, $\mathrm{NO}_{3}$, salinitas dan pH. Menurut da Costa et al. (2008) dan da Costa et al. (2011) salinitas dan temperatur merupakan dua faktor penting terhadap sebaran vertikal dan spasial, komposis jenis dan distribusi zooplankton di dalam perairan.

Menurut Baum (2008), pada awalnya muara Sungai Siak memiliki tingkat kesuburan yang rendah, kemudian karena pengaruh pembukaan lahan gambut sejak awal tahun 1970-an Sungai Siak menjadi subur. Hasil penelitian Baum (2008) menunjukkan muara Sungai Siak memiliki tingkat kesuburan yang sangat tinggi berasal pembukaan perkebunan kelapa sawit, industri dan limbah domestik dari pemukiman. Wöstmann dan Liebezeit (2012) menyatakan muara Sungai Siak merupakan zona pencampuran aktif bahan organik dari laut dan asal darat. Masukan bahan organik dari terestrial dalam jumlah yang sangat besar ke perairan sungai menyebabkan perairan menjadi subur. Aliran bahan organik dari hutan bakau yang masuk ke muara Sungai Siak pada akhirnya menjadi faktor penting bagi pertumbuhan dan perkembangan zooplankton serta biota lainnya.

Nilai indeks keanekaragaman spesies $\left(\mathrm{H}^{\prime}\right)$ menjelaskan tentang informasi berapa banyak jumlah individu dan jenis yang terdapat dalam suatu komunitas (Kadir et al., 2015). Zooplankton di muara Sungai Siak sangat beragam, hal ini dapat dilihat dari indeks keanekaragaman tergolong tinggi $(2,4-5,1)$. Sebagai pembanding, hasil penelitian Prianto et al. (2008) di Sungai Musi diperoleh nilai indeks keanekaragaman berkisar 0,5-2.2 dan Prianto et al. (2013) di Sungai Banyuasin sebesar 0,4-2.0. Hasil penelitian Pranoto et al. (2005) di muara sungai Serang-Jogjakarta diperoleh nilai indeks keanekaragaman berkisar 1,1-1,7 sedangkan di muara Sungai Mempawah berkisar 2,2-3,0 (Rahayu et al., 2013). Tingginya nilai indeks keanekaragaman ini menunjukkan zooplankton diperairan estuari Sungai Siak lebih beragam.
Ditinjau dari indeks keseragaman (E) yang nilainya berkisar 0,833-0,976 (mendekati 1) juga menunjukkan zooplankton di muara Sungai Siak dalam kondisi stabil. Satrioajie et al. (2021) menyebutkan kategori nilai indek keseragaman (E) yaitu: apabila nilai $0,00<\mathrm{E} \leq 0,50$ menunjukkan komunitas dalam kondisi tertekan; nilai $0,50<\mathrm{e} \leq 0,75$ komunitas dalam kondisi labil; dan nilai $0,75<\mathrm{E} \leq 1,00$ komunitas dalam kondisi stabil.

Dengan mengacu pada kedua nilai indeks di atas, terlihat bahwa estuari Sungai Siak cenderung stabil karena tingginya keanekaragaman. Tingginya keanekaragaman menunjukkan suatu ekosistem seimbang dan memberikan peranan besar untuk menjaga keseimbangan terhadap kejadian yang merusak ekosistem dan spesies dominan dalam suatu komunitas memperlihatkan kekuatan spesies itu dibandingkan spesies lain (Dianthani, 2003). Ekosistem yang tidak seimbang akan mempengaruhi pakan alami sehingga jika pakan alami tidak tersedia maka kelangsungan hidup larva organisme akan terancam.

Tingginya nilai indeks keanekaragaman zooplankton di muara Sungai Siak juga tidak terlepas dari faktor lingkungan seperti salinitas, suhu dan oksigen.Jika nilai H'>3 berarti sebaran individu tinggi atau keragaman tinggi berarti lingkungan tersebut belum mengalami gangguan (tekanan) atau struktur organisme yang ada berada dalam keadaan baik. Jika nilai $\mathrm{H}^{\prime}$ antara 1-3 berarti sebaran individu sedang atau keragaman sedang berarti lingkungan telah mengalami gangguan (tekanan) yang agak jelek. Sebaliknya jika $\mathrm{H}^{\prime}<1$ berarti sebaran individu rendah atau keragaman rendah berarti lingkungan tersebut telah mengalami gangguan (tekanan) atau struktur organisme yang ada berada dalam keadaan jelek. Namun, tampaknya untuk perairan estuari Sungai Siak kondisinya berbeda. Kendati beberapa penelitian sebelumnya menyatakan kualitas perairan ini khususnya di sub area hilir-muara memiliki pH dan DO rendah dan di bawah baku mutu, tampaknya belum mempengaruhi kepada keanekaragaman zooplankton di perairan ini. Pengaruhnya hanya terlihat terhadap kelimpahan dan jumlah jenis zooplankton yang terdapat di perairan tersebut.

Ditinjau dari indeks dominansi (D), di estuari Sungai Siak tidak ditemukan dominansi jenis zooplankton tertentu. Rata-rata nilai indeks dominansi selama waktu pengamatan di seluruh lokasi penelitian cukup rendah. Menurut Satrioajie et al. (2012) bahwa nilai indeks dominansi (D) berada pada kategori rendah ketika $0,00<\mathrm{D} \leq 0,50$, sedangkan kategori sedang untuk nilai $0,50<\mathrm{D} \leq 0,75$ dan dominansi tinggi ditunjukkan pada nilai $0,75<\mathrm{D} \leq 1,00$. Dengan demikian berarti keseimbangan komunitas zooplankton di estuari Sungai Siak menunjukkan kondisi yang relatif baik. Umumnya, apabila suatu komunitas memiliki nilai H' dan E tinggi, maka nilai D-nya cenderung rendah; menandakan kondisi komunitas yang stabil; sebaliknya apabila nilai $\mathrm{H}^{\prime}$ dan E rendah, maka nilai D-nya tinggi, menunjukkan ada dominansi suatu spesies terhadap spesies lain dan 
dominansi yang cukup besar akan mengarah pada kondisi komunitas yang labil atau tertekan.

Zooplankton di muara Sungai Siak didominasi oleh kelompok Ciliata dan Crustacea. Kelompok Ciliata yang banyak ditemukan Leprotintinnus nordgvisti dan Tintinnopsis radix memiliki peranan dalam rantai makanan dan dijadikan sebagai bio indikator pencemaran di perairan estuaria (Rakshit et al. 2017). Keberadaan ordo tintinnida seperti Leprotintinnus nordgvisti, Tintinnopsis beroidea, T. campanula, T. cylindrica, T. lobiancoi, di perairan mengindikasikan bahwa perairan tersebut tidak tercemar (Dorgham et al., 2013).

Tintinnida merupakan kelompok organisme yang cukup dominan diperairan Buzzard Bay dan jenis Tintinnopsis radix berasosiasi dengan dinoflagella parasit di perairan (Pierce \& Turner, 1994). Ordo tintinnida memiliki peran penting dalam transfer produksi pico dan nanoplankton ke meso dan makrometazoan predators. Namun demikian, faktor lingkungan musiman memberikan pengaruh besar terhadap tingkat komposisi jenis, kelimpahan, biomassa, produksi tintinnida (Godhantaraman, 2002) serta keberadaannya mengindikasikan perairan tersebut euryhaline (Godhantaraman, 2001).

Menurut Jerling (2003) zooplankton seperti halnya organisme lain hanya dapat hidup dan berkembang dengan baik pada kondisi perairan laut yang optimal seperti suhu, salinitas, dan DO, sehingga dapat mempengaruhi struktur komunitas zooplankton. Tampaknya, estuari Sungai Siak khususnya sub area Selat Padang, Selat Lalang dan Selat Bengkalis secara umum bisa mendukung kehidupan zooplankton secara optimal. Sementara bagian hilir dan mulut muara Sungai Siak yang diindikasikan sudah tercemar, menyebabkan kelimpahan dan kekayaan jenis/taxa di area ini lebih rendah. Informasi ini tentu sangat berarti bagi keberlanjutan sumberdaya ikan, yang larvanya hidup dan berkembang di estuari Sungai Siak dengan memanfaatkan zooplankton sebagai pakan alaminya.

\section{SIMPULAN}

Kelimpahan zooplankton diperairan estuari Sungai Siak relatif sama dengan perairan muara lainnya. Dilihat dari struktur komunitas zooplankton, perairan estuari Sungai Siak dalam kondisi yang stabil dengan tingkat keanekaragaman dan keseragaman yang tinggi dan tidak ditemukan dominansi jenis tertentu. Ini menunjukkan kondisi perairan muara Sungai Siak masih tergolong baik untuk mendukung kehidupan zooplankton. Tingkat kecerahan perairan berpengaruh signifikan, pada saat kecerahan rendah, jumlah jenis zooplankton di perairan ini sangat rendah. Umumnya, zooplankton di estuari Sungai Siak didominasi oleh kelompok Ciliata dan Crustacea. Zooplankton dari kelompok Ciliata yakni jenis Leprotintinnus nordgvisti dan Tintinnopsis radix merupakan jenis yang cukup dominan ditemukan dibandingkan jenis lainnya, keberadaan spesies ini menunjukkan bahwa perairan belum tercemar. Sementara keberadaan Copepoda dari kelompok Crustasea, dapat mendukung ketersediaan pakan alami larva ikan dan udang di perairan ini.

\section{UCAPAN TERIMA KASIH}

Tulisan ini merupakan kontribusi dari hasil kegiatan penelitian "Analisa Daya Dukung Lingkungan Kawasan Konservasi Ikan Terubuk" kerjasama antara Dinas Kelautan dan Perikanan Kabupaten Bengkalis (DIPA TA 2015) dengan Balai Riset Perikanan Laut, Pusat Riset Perikanan, Kementerian Kelautan dan Perikanan, Jakarta. Kami mengucapkan terima kasih kepada Dinas Kelautan dan Perikanan Kabupaten Bengkalis dan tim yang membantu survei termasuk crew kapal survei KM. Tenuallosa.

\section{DAFTAR PUSTAKA}

American Public Health Association (APHA). (1980). Standard Methods for the Examination of Water and Waste Water. New York: American Public Health Association Inc.

Amri K, Winarso G \& Muchlizar. (2018-a). Kualitas Lingkungan Perairan dan Potensi Produksi Ikan Kawasan Konservasi Terubuk Bengkalis (Tenualosa macrura Bleeker, 1852). Jurnal Penelitian Perikanan Indonesia, 24, (1), 3-8.

Amri K, Priatna A \& Muchlizar. (2018-b). Karakteristik Oseanografi Fisika Perairan Estuaria Bengkalis Berdasarkan Data Pengukuran In-Situ. Jurnal Segara, 14, (1), 43-56.

Amri K, Muchlizar \& Ma'mun A. (2018-c). Variasi Bulanan Salinitas, $\mathrm{pH}$ dan Oksigen Terlarut di Perairan Estuari Bengkalis. Majalah Ilmiah Globe, 20, (2), 58-67.

Ariana D, Samiaji J \& Nasution S. (2014). Komposisi Jenis dan Kelimpahan Fitoplankton di Perairan Laut Riau. Jurnal Online Mahasiswa (JOM) Fakultas Perikanan dan Ilmu Kelautan Universitas Riau, 1,(1), 1-15.

Barnes RSK. (1974). Estuarine Biology. London: Edward Arnold.

Baum A. (2008). Tropical Black Water Biogeochemistry: The Siak River in Central Sumatera, Indonesia. Bremen: Bremen University.

da Costa KG, Periera LCC \& da Costa RM. (2008). Short and Long Term Temporal Variation of the Zooplankton in a Tropical Estuary (Amazon Region Brazil). Bol. Mus. Para Emilio Goeldi. Ciencias Naturais, 3,(2), 127-141.

da Costa RM, Atique P, da Costa KG \& Periera LCC. (2011). Seasonal and Spatial Variation in Hydrological Parameters and Microzooplankton Communities in an Amazonian Estuary. Journal of Coastal Research, SI 64 (Proceedings of the 11th International Coastal Symposium), 1477-1481. 
Dianthani D. (2003). Identifikasi Jenis Plankton di Perairan Muara Badak, Kalimantan Timur. Makalah Falsafah Sains. Program Pascasarjana IPB. Bogor. 73p.

Dorgham MM, El-Tohamy WS, Aziz NEA, ElGhobashi A \& Qin JG. (2013). Protozoa in a Stressed Area of the Egyptian Mediterranean Coast of Damietta, Egypt. Oceanologia, 55,(3), 733-750.

Dwirastina M. (2013). Pengamatan Kelimpahan Zooplankton Daerah Marempan di Sungai Siak Riau. Buletin Teknik Litkayasa, 11, (1), 1-4.

Efizon D dan Alit HY. (2003). Dampak KepMen KP Nomor Kep.59/MEN/2011 Tentang Penetapan Status Perlindungan Terbatas Jenis Ikan Terubuk (Tenualosa macrura) dalam Meningkatkan Populasi Ikan Terubuk di Provinsi Riau. Bahan Presentasi (tidak dipublikasikan). Universitas Riau. Pekanbaru.

Efizon D, Djunaedi OS, Dhahiyat Y \& Koswara B. (2012). Kelimpahan Populasi dan Tingkat Eksploitasi Ikan Terubuk (Tenualosa macrura) di Perairan Bengkalis, Riau. Berkala Perikanan Terubuk, 40, (1), 52-65.

Fajri NE \& Kasry A. (2013). Kualitas Perairan Muara Sungai Siak Ditinjau dari Sifat Fisik-Kimia dan Makrozoobentos. Berkala Perikanan Terubuk, 41, (1), 37-52.

Godhantaraman N. (2001). Seasonal Variations in Taxonomic Compotition, Abundance and Food Web Relationship of Microzooplankton in Estuarine and Mangrove Waters, Parangi Pettai Region, Southeast Coast of India. Journal of Marine Systems, 30, (3), 151-60.

Godhantaraman N. (2002). Seasonal Variations in Species Composition, Abundance, Biomass and Estimated Production Rates of Tintinnids at Tropical Estuarine and Mangrove Waters, Parangi Pettai, Southeast Coast of India. Journal of Marine Systems, 36, (3-4), 161-71.

Handayani S \& Patria MP. (2005). Komunitas Zooplankton di Perairan Waduk Krenceng, Cilegon, Banten. Jurnal Makara Sains, 9, (2), 7580.

Jerling HL (2003). The Zooplankton Community of the Mhlathuze (Richard Bay) Estuary: Two Decades After Construction of the Harbour. African Journal of Marine Science, 25, 289-99.

Kadir MA, Damar A \& Krisanti, M. (2015). Dinamika Spasial dan Temporal Struktur Komunitas Zooplankton di Teluk Jakarta. Jurnal Ilmu Pertanian Indonesia, 20, (3), 247-56.

Kasry A \& El Fajri N. (2012). Kualitas Perairan Muara Sungai Siak Ditinjau dari Parameter Fisika-Kimia dan Organisme Plankton. Jurnal Berkala Perikanan Terubuk, 40, (2), 96-113.

Ludwig JA \& Reynolds JF. (1988). Statistical Ecology. New York: Wiley.

Merta GS, Wasilun, Wagiyo K, Girsang ES \& Suprapto. (1999). Status Populasi dan Bio-Ekologi Ikan
Terubuk Tenualosa macrura (Clupeidae) di Provinsi Riau. Jurnal Penelitian Perikanan Indonesia, 5, (3), 15-29.

Mishra S \& Panigrahy RC. (1999). Zooplankton Ecology of the Bahuda Estuary (Orissa), East Coast of India. Indian Journal of Marine Sciences, 28, 297-301.

Nontji A. (2008). Plankton Laut. Jakarta: LIPI Press.

Nybakken JW. (1992). Biologi Laut. Suatu Pendekatan Ekologis. Jakarta: PT. Gramedia Pustaka Utama.

Odum EP. (1993). Dasar-Dasar Ekologi. Edisi ke-3. Yogyakarta: Gadjah Mada University Press.

Odum EP. (1998). Dasar-dasar Ekologi. Edisi ke-3. ed. dan Alih Bahasa: Samingan dan Srigandono. Yogyakarta: Universitas Gadjah Mada Press.

Paterson MJ. (1998). Ecological Monitoring and Assessment Network (Eman) Protocols for Measuring Biodiversity: Zooplankton in Fresh Waters. Manitoba: Department of Fisheries and Oceans Freshwater Institute 501 University Crescent Winnipeg.

Pielou EC. (1975). Ecological Diversity. New York: John Wiley \& Sons.

Pierce RW \& Turner JT. (1994). Plankton Studies in Buzzards Bay, Massachusetts, USA. IV. Tintinnids, 1987 to 1988. Marine Ecology Progress Series, 112, 235-40.

Pranoto BA, Ambariyanto \& Zainuri M. (2005). Struktur Komunitas Zooplankton di Muara Sungai Serang, Jogjakarta. Ilmu Kelautan, 10, (2), 90-97.

Pratiwi NTM, Wulandari ADY \& Iswantari A. (2016). Horizontal Distribution of Zooplankton in Tangerang Coastal Waters, Indonesia. The 2nd International Symposium on LAPAN-IPB Satelite for Food Security and Environment Monitoring 2015. LISAT-FSEM 2015. Preceeding Environment (pp 470-477). Bogor: Institut Pertanian Bogor.

Prianto E, Husnah \& Aida SN. (2008). Inventarisasi Jenis dan Struktur Ekologi Zooplankton di Sungai Musi Bagian Hilir. Jurnal Penelitian dan Perikanan Indonesia, 14, (3), 263-271.

Prianto E, Husnah \& Aprianti S. (2013). Komposisi Jenis dan Struktur Ekologi Zooplankton di Sungai Banyuasin Sumatera Selatan. Prosiding Pertemuan Ilmiah Tahunan Masyarakat Limnologi Indonesia (pp 192-203). Cibinong: Pusat Penelitian Limnologi Lembaga Ilmu Pengetahuan Indonesia (LIPI).

Rahayu S, Evawani \& Yuliati. (2014). Diversity of Plankton in the Part of Upstream Siak River Palas Village, Pekanbaru City, Riau Province. Jurnal Online Mahasiswa (JOM) Fakultas Perikanan dan Ilmu Kelautan Universitas Riau, 1, (1), 1-15.

Rahayu S, Setyawati TR \& Turnip M. (2013). Struktur Komunitas Zooplankton di Muara Sungai Mempawah Kabupaten Pontianak Berdasarkan Pasang Surut Air Laut. Protobiont, 2, (2), 49-55.

Rakshit D, Marugan K, Biswas JK \& Sarkar SK. (2017). 
Environmental Impact on Diversity and Distribution of Tintinnid (Ciliata: Protozoa) Along Hooghly Estuary, India: A Multivariate Approach.” Regional Studi in Marine Science, 12, $1-10$.

Rahman A, Haryadi J, Sentosa AA \& Mujiyanto. (2017). Kajian Awal Kemunculan Hiu Paus (Rhyncodon typus, Smith 1828) di Teluk Tomini Dihubungkan dengan Faktor Fisik dan Biologi Perairan. Jurnal Akuatika Indonesia, 2, (2), 128-136.

Rositasari, Ricky \& Rahayu SK. (1994). Sifat-Sifat Estuari dan Pengelolaannya. Oseana, 19, (3), 2131.

Satrioajie WNT, Peristiwady \& La Pay. (2012). Keanekaragaman Ikan di daerah Padang Lamun Kepulauan Banggai, Sulawesi Tengah. Bawal, 4, (1), 9-17.

Silva AMA, Barbosa JEL, Medeiros PR, Rocha RM, Lucena-Filho MA \& Silva DF. (2009). Zooplankton (Cladocera and Rotifera) Variations Along a Horizontal Salinity Gradient and During Two Seasons (Dry and Rainy) in a Tropical Inverse Estuary (Northeast Brazil). Pan-American Journal of Aquatic Sciences, 4, (2), 226-237.

Soedarsono P, Subiyanto, Niniek W \& Sahala H. (2002). Petunjuk Praktikum Planktonologi. Universitas Diponoegoro. Semarang.
Souza Júnior AN, Magalhães A, Pereira LCC \& Costa RM. (2013). Zooplankton Dynamics in a Tropical Amazon Estuary. Journal of Coastal Research, ed. T.J. (eds.) In: Conley DC, Masselink G, Russell PE \& O'Hare. Plymouth, England: Proceedings 12th International Coastal Symposium, 1230-1235.

Suwarso \& Merta IG. (2003). Penurunan Populasi dan Alternatif Pengelolaan Ikan Terubuk, Tenualosa macrura (Clupeidae), di Provinsi Riau. Jurnal Penelitian Perikanan Indonesia, 6, (2), 25-36.

Tomas CR (1997). Indentifying marine phytoplankton. St. Petersburg, Florida: Academic Press.

Wedderburn S, Shiel R, Hillyard K \& Brookes J. (2010). Zooplankton Response to Watering of an Offchannel Site at the Lower Lakes and Implications for Murray Hardyhead Recruitment. Adelaide: The University of Adelaide.

Wiadnyana NN. (2000). Kemelimpahan Plankton di Perairan Selat Sele, Sorong, Irian Jaya. Majalah Ilmu Kelautan, 17,(5), 19-28.

Wöstmann R \& Liebezeit G. (2012). Geochemical Evidence for Different Peat Sources in the Siak Estuary and Along the East Coast of Sumatra, Indonesia. Mires and Peat, 10,(2), 1-13.

Yamaji CS. (1979). Illustrations of the marine plankton of Japan. Osaka: Hoikusha Publishing Co. Ltd. 


\section{LAMPIRAN 1:}

Tabel 4 Nilai indek biologi zooplankton di perairan estuari Sungai Siak, 2015

\begin{tabular}{|c|c|c|c|c|c|c|c|c|c|c|c|c|c|c|c|c|c|}
\hline \multirow{2}{*}{ Bulan } & \multirow{2}{*}{ Indeks } & \multicolumn{16}{|c|}{ No. Stasiun Sampling } \\
\hline & & 1 & 2 & 3 & 4 & 5 & 6 & 7 & 8 & 9 & 10 & 11 & 12 & 13 & 14 & 15 & 16 \\
\hline \multirow{3}{*}{ April } & $\mathrm{H}^{\prime}$ & 3.7 & 3.81 & 3.81 & 3.7 & 3.91 & 3.78 & 3.63 & 3.49 & 3.56 & 3.64 & 3.5 & 3.44 & 3.66 & 3.69 & 3.68 & 3.55 \\
\hline & $\mathrm{E}$ & 0.94 & 0.96 & 0.93 & 0.97 & 0.96 & 0.95 & 0.95 & 0.92 & 0.94 & 0.94 & 0.96 & 0.94 & 0.93 & 0.98 & 0.95 & 0.95 \\
\hline & $\mathrm{D}$ & 0.1 & 0.1 & 0.1 & 0.1 & 0.09 & 0.08 & 0.09 & 0.1 & 0.09 & 0.09 & 0.1 & 0.18 & 0.09 & 0.09 & 0.08 & 0.1 \\
\hline \multirow{3}{*}{ Mei } & $\mathrm{H}^{\prime}$ & 3.47 & 3.27 & 3.47 & 3.53 & 3.62 & 3.61 & 3.68 & 3.35 & 3.61 & 3.66 & 3.55 & 3.31 & 3.27 & 3.31 & 3.35 & 3.48 \\
\hline & $\mathrm{E}$ & 0.94 & 0.91 & 0.94 & 0.93 & 0.95 & 0.95 & 0.94 & 0.94 & 0.95 & 0.94 & 0.96 & 0.92 & 0.94 & 0.92 & 0.91 & 0.94 \\
\hline & $\mathrm{D}$ & 0.1 & 0.12 & 0.1 & 0.1 & 0.09 & 0.09 & 0.09 & 0.11 & 0.09 & 0.09 & 0.09 & 0.11 & 0.11 & 0.11 & 0.12 & 0.1 \\
\hline \multirow{3}{*}{ Juni } & $\mathrm{H}^{\prime}$ & 3.67 & 3.52 & 3.58 & 3.61 & 3.36 & 3.6 & 3.65 & 3.48 & 3.37 & 3.51 & 3.56 & 3.7 & 3.5 & 3.58 & 3.16 & 3.5 \\
\hline & $\mathrm{E}$ & 0.94 & 0.93 & 0.96 & 0.9 & 0.91 & 0.94 & 0.93 & 0.91 & 0.9 & 0.95 & 0.93 & 0.95 & 0.94 & 0.97 & 0.91 & 0.92 \\
\hline & $\mathrm{D}$ & 0.09 & 0.1 & 0.09 & 0.34 & 0.1 & 0.09 & 0.09 & 0.11 & 0.1 & 0.1 & 0.08 & 0.08 & 0.34 & 0.09 & 0.12 & 0.1 \\
\hline \multirow{4}{*}{ Agustus } & $\mathrm{H}^{\prime}$ & 4.98 & 5.02 & 5.14 & 4.96 & 5.03 & 4.85 & 5.07 & 4.86 & 5.14 & 5.12 & 4.95 & 5.11 & 5.05 & 5.13 & 5.16 & 5.09 \\
\hline & $\mathrm{E}$ & 0.91 & 0.89 & 0.92 & 0.88 & 0.9 & 0.84 & 0.89 & 0.9 & 0.92 & 0.9 & 0.89 & 0.9 & 0.9 & 0.9 & 0.91 & 0.89 \\
\hline & $\mathrm{D}$ & 0.09 & 0.11 & 0.1 & 0.12 & 0.1 & 0.09 & 0.08 & 0.09 & 0.1 & 0.09 & 0.1 & 0.11 & 0.09 & 0.09 & 0.1 & 0.09 \\
\hline & $\mathrm{H}^{\prime}$ & 2.97 & 3.19 & 3.09 & 3.08 & 3.19 & 3.28 & 3.42 & 3.05 & 3.13 & 3.12 & 2.87 & 2.82 & 3.32 & 3.38 & 3.0 & 2.45 \\
\hline \multirow[t]{3}{*}{ September } & $\mathrm{E}$ & 0.94 & 0.96 & 0.93 & 0.97 & 0.96 & 0.95 & 0.95 & 0.92 & 0.94 & 0.94 & 0.96 & 0.94 & 0.93 & 0.98 & 0.95 & 0.95 \\
\hline & $\mathrm{D}$ & 0.14 & 0.12 & 0.13 & 0.12 & 0.12 & 0.12 & 0.1 & 0.13 & 0.13 & 0.13 & 0.14 & 0.16 & 0.12 & 0.1 & 0.14 & 0.2 \\
\hline & $\mathrm{H}^{\prime}$ & 3.55 & 3.28 & 3.37 & 3.35 & 3.19 & 3.51 & 3.52 & 3.4 & 3.74 & 3.68 & 3.55 & 3.62 & 3.61 & 3.69 & 3.45 & 3.68 \\
\hline \multirow[t]{3}{*}{ Oktober } & $\mathrm{E}$ & 0.87 & 0.86 & 0.86 & 0.86 & 0.84 & 0.88 & 0.86 & 0.85 & 0.94 & 0.94 & 0.93 & 0.93 & 0.92 & 0.92 & 0.88 & 0.94 \\
\hline & $\mathrm{D}$ & 0.08 & 0.1 & 0.09 & 0.09 & 0.1 & 0.08 & 0.08 & 0.09 & 0.08 & 0.09 & 0.09 & 0.09 & 0.09 & 0.09 & 0.12 & 0.08 \\
\hline & $\mathrm{H}^{\prime}$ & 3.51 & 3.38 & 3.55 & 3.31 & 3.58 & 3.54 & 2.57 & 3.4 & 3.36 & 3.3 & 3.55 & 3.43 & 3.33 & 3.55 & 3.6 & 3.48 \\
\hline \multirow[t]{2}{*}{ November } & $\mathrm{E}$ & 0.95 & 0.94 & 0.93 & 0.96 & 0.92 & 0.93 & 0.9 & 0.95 & 0.94 & 0.95 & 0.93 & 0.96 & 0.95 & 0.93 & 0.92 & 0.94 \\
\hline & $\mathrm{D}$ & 0.09 & 0.11 & 0.09 & 0.11 & 0.1 & 0.1 & 0.42 & 0.1 & 0.11 & 0.11 & 0.1 & 0.1 & 0.09 & 0.09 & 0.09 & 0.1 \\
\hline
\end{tabular}

Keterangan: $H^{\prime}$ = Indeks Keanekaragaman; E = Indeks Keseragaman; D = Indeks Dominansi 